\title{
Blood chemistry of bacterial gill disease in brook trout Salvelinus fontinalis
}

\author{
P. Byrne, H. W. Ferguson* , J. S. Lumsden, V. E. Ostland \\ Fish Pathology Laboratory, Department of Pathology, Ontario Veterinary College, University of Guelph, \\ Ontario, Canada N1G 2W1
}

\begin{abstract}
Blood chemistry was examined in brook trout Salvelinus fontinalis suffering from bacterial gill disease (BGD) and compared to normal healthy fish under identical conditions. Infected fish showed a marked decrease in serum $\mathrm{Na}^{+}, \mathrm{Cl}^{-}$and in osmolality, and a concommitant haemoconcentration as indicated by the increased serum protein and increased packed cell volume. Fish with BGD exhibited an increased rate of respiration (tachybranchia) but were not hypoxemic, suggesting that compensatory mechanisms, such as tachybranchia and enhanced recruitment of lamellar reserves, were successful. Nevertheless, the cause of the tachybranchia in BGD-infected fish remains unexplained; it may not be a response to impaired oxygen exchange, although this seems the most likely explanation. The acid-base status did not differ between healthy and diseased fish. These findings suggest that changes in blood components other than acid-base ones constitute the critical, and sometimes fatal changes occurring as a result of BGD infection, rather than hypoxemia. It is suggested that circulatory disturbances resulted from the rapid drop of blood electrolytes, which in turn triggered a fluid shift from the extracellular to the intracellular compartments, leading to haemoconcentration and death. However caused, tachybranchia probably exacerbated the worsening blood chemistry changes resulting from damaged gill epithelium. The implications of these findings for treatment include reducing the rate of ion loss from the gills by raising the salt levels in the water, combined with other chemicals directed specifically at the bacteria.
\end{abstract}

\section{INTRODUCTION}

Bacterial gill disease (BGD) affects a variety of farmed fish worldwide. It is a common disease problem in farmed salmonids in North America; in Ontario (Canada) it represents one of the most significant causes of loss in trout hatcheries (Daoust \& Ferguson 1983, Speare \& Ferguson 1989). Much of the descriptive pathology for the naturally-occurring disease now exists (Kudo \& Kimura 1983, 1984, Speare et al. 1991a, b), and the usually effective treatment of fish using either chloramine-T (Bullock \& Herman 1988), or dilute formalin, is now well established. However, there is virtually no information on the pathogenesis or pathophysiology of the disease. In particular, the precise reason(s) for the marked respiratory distress of affected fish remain poorly understood, although impaired uptake of oxygen is thought to be the prime cause (Rucker et al. 1952, Kudo \& Kimura 1984).

\footnotetext{
- Addressee for correspondence
}

One of the major impediments to investigating the pathophysiology further may lie in the fact that BGD most commonly affects younger trout during the fry-tofingerling stages, and blood samples of sufficient size for complete blood chemistry from individual fish are thus difficult to obtain. Recently, however, we diagnosed BGD in some brook trout Salvelinus fontinalis which were big enough (20 to $25 \mathrm{~cm}$ ) to give individual blood samples of sufficient volume.

\section{MATERIALS AND METHODS}

History. Infected Salvelinus fontinalis were all from a single holding tank supplied with aerated water at $10{ }^{\circ} \mathrm{C}$ on a flow-through basis. Fish were lethargic and inappetant; they were hanging near the water surface, and had increased branchial movements. Several fish were killed using an overdose of MS-222 (tricaine methanesulfonate; Crescent Research Chemicals, Phoenix, AR) neutralized with $\mathrm{NaOH}$. Gill scrapings examined under whole-mount showed the presence of 
large numbers of filamentous bacteria covering the respiratory surfaces. Tissues taken for routine histopathological examination subsequently confirmed the tentative diagnosis of BGD according to well-established criteria (Ostland et al. 1990). Another identical tank containing healthy fish provided good controls for comparison.

Sampling protocol. The first set of blood and tissue samples (Day 1) included 11 diseased fish and 11 healthy (control) fish. Additional blood and tissue samples were obtained 3 d later (Day 4) from 6 diseased and 5 healthy trout.

Fish were randomly selected for sampling, and immediately transferred by dip-net to aerated water containing 1:10000 MS-222 neutralized with $\mathrm{NaOH}$. After anaesthesia, fish were removed from the water for blood and tissue sampling. On Day 4 only, irrigation of the branchial cavity was begun soon after fish were removed from the water with the same aerated water used for anaesthesia. Branchial irrigation was continued for the duration of blood sampling.

Blood destined for acid-base analysis was collected using one of 2 methods, depending on the day of sampling. Day 1 samples were collected from the severed base of the first gill arch using a 200 to $230 \mu \mathrm{l}$ heparinized glass tube (Clinitubes ${ }^{\mathrm{TM}}$, Radiometer, Copenhagen NV). Day 4 samples were collected from the dorsal aorta using a $3 \mathrm{ml}$ acid-base syringe containing heparin. Acid-base samples were stored in ice until analysis ( 1 to $1.5 \mathrm{~h}$ ). Serum lactate concentration was determined (YSI, model 23L, Yellow Springs, Ohio) on Day 4 only, from the acid-base sample.

Blood destined for analysis of non-acid-base components (i.e. serum electrolytes, protein and osmolality) was collected using one of 2 methods, depending on the day of collection. Day 1 samples were collected from the caudal vein, Day 4 samples from the dorsal aorta. Blood for electrolyte and protein analysis was collected only after acid-base samples had been obtained. Gill arches were removed from each fish immediately following blood sampling ( $\leq 2 \mathrm{~min})$ and placed in Bouin's fixative for subsequent paraffin wax embedding and routine processing for histopathology.

Analysis. Details regarding methods employed for blood analysis can be obtained from Byrne et al. (1989). Briefly, electrolytes, proteins and osmolality were determined from serum, collected from centrifuged, whole blood $(800 \times g$ for $10 \mathrm{~min})$. Packed cell volume (pcv) was determined using heparinized microhaematocrit tubes. Tubes were held on ice until they could be centrifuged and then read (1 to $1.5 \mathrm{~h}$ ). Serum was stored at $-20{ }^{\circ} \mathrm{C}$ ( 1 to $4 \mathrm{~d}$ ) until analysis. Acid-base analysis $\left(\mathrm{pH}, \mathrm{TCO}_{2}, \mathrm{pCO}_{2}, \mathrm{pO}_{2}, \mathrm{HCO}_{3}\right.$ and actual base excess $[A B E]$ ) was performed on a radiometer (ABL3, Copenhagen NV) at $37^{\circ} \mathrm{C}$ and recalculated to the ambient temperature of the fish $\left(10^{\circ} \mathrm{C}\right)$ using $\mathrm{ABL} 3$ formulas. Formulas used to estimate $\mathrm{TCO}_{2}, \mathrm{HCO}_{3}$ and $\mathrm{ABE}$ were slightly modified in that a solubility coefficient of $\mathrm{CO}_{2}$ more closely approximating that of fish plasma was used (0.064 mmol $\mathrm{l}^{-1}$ torr $^{-1}$, Heming 1989) in place of $0.0306 \mathrm{mmol} \mathrm{l}^{-1}$ torr $^{-1}$ as used in standard radiometer formulations.

Results of Day 1 blood chemistry changes were statistically compared using one of 2 t-tests available from $\mathrm{SAS}^{\circledR} \quad$ (Statistical Analysis System, version 5.18) depending on the equality of treatment variances. For unequal variances, Satterthwaite's (1946) approximation was used (SAS ${ }^{\circledR}$ User's Guide: Statistics, version 5). Day 4 blood chemistry results were compared using the Kruskal-Wallis, non-parametric test (Hollander \& Wolfe 1973). This was necessary because of the small sample sizes of Day 4 samples which renders the $t$-test invalid. Comparisons between control and diseased fish were made within sampling days only, because of the differences in sampling techniques between days. The $\alpha$ level of significance was 0.05 for all statistical tests.

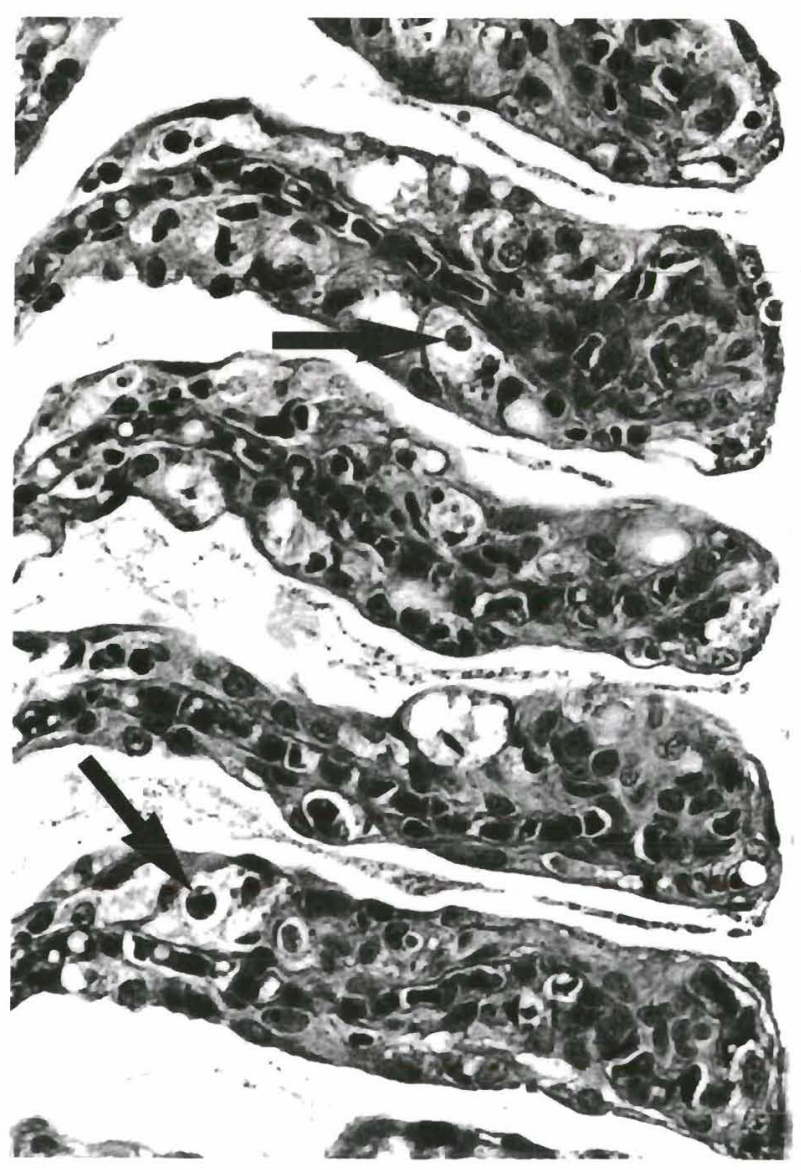

Fig. 1. Salvelinus fontinalis. Micrograph of gills from brook trout with bacterial gill disease showing high power view of several hyperplastic lamellae with bacteria between. Several necrotic cells can be seen within the epithelium (arrows), and there is accompanying edema $(\times 450)$ 


\section{RESULTS}

\section{Histopathology}

Fish with BGD showed varying degrees of severity and chronicity, but all gills had moderate-to-large numbers of filamentous bacteria on the lamellar and filamental surfaces. Changes included lamellar fusion, pavement cell hypertrophy and hyperplasia, invasion of inflammatory cells beneath the lamellar epithelium and into the central venous sinus, necrosis of individual epithelial cells, and the formation of residual bodies (Fig. 1). Gills from all of the control fish were normal.

\section{Clinical chemistry}

Table 1 shows the results of the blood-gas and serum chemistry analyses. Marked changes occurred in most serum electrolyte, protein and osmolality profiles, in contrast to only one significant difference from the acidbase variables $\left(\mathrm{pCO}_{2}\right.$ was lower in diseased fish on Day 1 only). Because of low volumes of blood collected on Day 4, only serum $\mathrm{Na}^{+}, \mathrm{Cl}^{-}, \mathrm{K}^{+}$and lactate were

Table 1. Salvelinus fontinalis. Blood chemistry of brook trout with bacterial gill disease (sick) and without BGD (healthy)

\begin{tabular}{|c|c|c|c|c|}
\hline \multirow{2}{*}{$\begin{array}{l}\text { Blood chemistry } \\
\text { factor }\end{array}$} & \multicolumn{2}{|c|}{ Day $1^{a}$} & \multicolumn{2}{|c|}{ Day 4} \\
\hline & Healthy & Sick & Healthy & Sick \\
\hline \multirow[t]{2}{*}{$\mathrm{pH}$} & $7.54 \pm 0.01^{\mathrm{b}}$ & $7.63 \pm 0.04$ & $7.81 \pm 0.02$ & $7.77 \pm 0.01$ \\
\hline & 9 & 9 & 5 & 6 \\
\hline \multirow[t]{2}{*}{$\mathrm{pCO}_{2}(\mathrm{mmHg})$} & $11.84 \pm 0.41$ & $9.71 \pm 0.39^{\circ}$ & $8.52 \pm 0.41$ & $8.41 \pm 0.38$ \\
\hline & 9 & 9 & 5 & 6 \\
\hline \multirow[t]{2}{*}{$\mathrm{pO}_{2}(\mathrm{mmHg})$} & $0.33 \pm 0.15$ & $16.52 \pm 7.02^{\mathrm{c}}$ & $4.33 \pm 1.10$ & $4.02 \pm 0.35$ \\
\hline & 5 & 7 & 5 & 6 \\
\hline \multirow[t]{2}{*}{$\mathrm{HCO}_{3}\left(\mathrm{mmol} \mathrm{l}^{-1}\right)$} & $21.5 \pm 1.3$ & $22.5 \pm 2.0$ & $29.3 \pm 1.3$ & $26.7 \pm 1.6$ \\
\hline & 9 & 9 & 5 & 6 \\
\hline \multirow[t]{2}{*}{$\mathrm{TCO}_{2}\left(\mathrm{mmol} \mathrm{l}^{-1}\right)$} & $22.3 \pm 1.3$ & $23.2 \pm 2.0$ & $29.8 \pm 1.3$ & $27.2 \pm 1.6$ \\
\hline & 9 & 9 & 5 & 6 \\
\hline \multirow[t]{2}{*}{$\mathrm{ABE}^{\mathrm{d}}\left(\mathrm{mmol} \mathrm{l}^{-1}\right)$} & $-19.1 \pm 0.9$ & $-19.2 \pm 1.1$ & $-15.7 \pm 0.77$ & $-16.6 \pm 9.1$ \\
\hline & 9 & 9 & 5 & 6 \\
\hline \multirow[t]{2}{*}{$\mathrm{Na}\left(\mathrm{mmol} \mathrm{l} \mathrm{l}^{-1}\right)$} & $157.1 \pm 0.7$ & $138.2 \pm 2.3^{\circ}$ & $158.08 \pm 1.1$ & $136.4 \pm 2.7^{\bullet}$ \\
\hline & 11 & 11 & 5 & 6 \\
\hline \multirow[t]{2}{*}{$\mathrm{K}\left(\mathrm{mmol} \mathrm{l}^{-1}\right)$} & $2.5 \pm 0.3$ & $5.6 \pm 0.7^{\circ}$ & $1.9 \pm 0.2$ & $4.3 \pm 0.6^{\bullet}$ \\
\hline & 11 & 11 & 5 & 6 \\
\hline \multirow[t]{2}{*}{$\mathrm{Cl}\left(\mathrm{mmol} \mathrm{l}^{-1}\right)$} & $127.3 \pm 0.9$ & $112.0 \pm 1.5^{\circ}$ & $128.6 \pm 1.6$ & $111.7 \pm 2.9^{\circ}$ \\
\hline & 11 & 11 & 5 & 6 \\
\hline Osmolality (mOsm) & $\begin{array}{c}321.4 \pm 1.3 \\
10\end{array}$ & $\begin{array}{c}296.4 \pm 1.9^{\circ} \\
11\end{array}$ & ND & ND \\
\hline $\mathrm{Mg}\left(\mathrm{mmol} \mathrm{l}^{-1}\right)$ & $1.8 \pm 0.0$ & $\begin{array}{c}1.4 \pm 0.1^{\circ} \\
11\end{array}$ & ND & ND \\
\hline $\mathrm{Ca}\left(\mathrm{mmol} \mathrm{l}^{-1}\right)$ & $3.0 \pm 0.2$ & $\begin{array}{c}2.8 \pm 0.1 \\
11\end{array}$ & ND & ND \\
\hline Tot. protein $\left(\mathrm{g} \mathrm{l}^{-1}\right)$ & $\begin{array}{c}28.2 \pm 1.8 \\
10\end{array}$ & $\begin{array}{c}36.9 \pm 2.4^{\circ} \\
11\end{array}$ & ND & ND \\
\hline Albumin $\left(\mathrm{g} \mathrm{l}^{-1}\right)$ & $\begin{array}{c}9.9 \pm 0.6 \\
10\end{array}$ & $\begin{array}{c}13.3 \pm 1.1^{\circ} \\
11\end{array}$ & ND & ND \\
\hline Globulin $\left(\mathrm{g} \mathrm{l}^{-1}\right)$ & $\begin{array}{c}18.3 \pm 1.3 \\
10\end{array}$ & $\begin{array}{c}23.6 \pm 1.4^{\circ} \\
11\end{array}$ & ND & ND \\
\hline Albumin/globulin & $\begin{array}{c}0.554 \pm 0.026 \\
10\end{array}$ & $\begin{array}{c}0.554 \pm 0.024 \\
11\end{array}$ & ND & ND \\
\hline Packed cell vol. (\%) & $\begin{array}{c}28.2 \pm 1.3 \\
10\end{array}$ & $\begin{array}{c}36.5 \pm 1.1^{\circ} \\
11\end{array}$ & ND & ND \\
\hline Lactate $\left(\mathrm{mmol} \mathrm{l}^{-1}\right)$ & ND & ND & $3.13 \pm 0.65$ & $3.26 \pm 0.89$ \\
\hline \multicolumn{5}{|c|}{$\begin{array}{l}{ }^{a} \text { Day } 1 \text { samples were compared using a } t \text {-test, whereas Day } 4 \text { samples were compared non-parametrically using the Kruskal- } \\
\text { Wallis test } \\
\text { b Data represent means followed by standard errors and sample size (below) }\end{array}$} \\
\hline \multicolumn{5}{|c|}{$\begin{array}{l}{ }^{\mathrm{c}} \text { Day } 1 \mathrm{pO}_{2} \text { values appeared too unreliable (numerous negative estimates and relatively large, unequal variances) and thus } \\
\text { inappropriate for statistical comparison. For tabulation herein, negative } \mathrm{pO}_{2} \text { values were excluded } \\
{ }^{\mathrm{d}} \text { Actual base excess }\end{array}$} \\
\hline
\end{tabular}


determined in addition to acid-base analysis. Serum $\mathrm{Na}^{+}$and $\mathrm{Cl}^{-}$decreased, while $\mathrm{K}^{+}$increased in diseased fish from both sampling days. In addition, diseased fish on Day 1 had decreased serum osmolality and elevated serum protein and packed cell volume (pcv).

\section{DISCUSSION}

These results are only preliminary but they do provide some insight into why fish with BGD become sick and often die. Following damage to the respiratory epithelium by bacteria, there were dramatic reductions in serum $\mathrm{Na}^{+}, \mathrm{Cl}^{-}$and in osmolality, in conjunction with a rise in $\mathrm{pcv}$ and serum protein and $\mathrm{K}^{+}$. Surprisingly, little change was seen with the acid-base status of the fish. We suggest that these haematological disturbances are possibly the most relevant changes that ultimately lead to death in cases of BGD. The effect that elevated serum $\mathrm{K}^{+}$may have on the cardiovascular function of the these fish (such as the bradycardia that occurs in mammals) in unknown. Based on these results a model is proposed to explain some of the key events in BGD (Fig. 2).

Recent studies with trout indicate that in strictly hypoxic situations, plasma $\mathrm{Na}^{+}$and $\mathrm{Cl}^{-}$are usually elevated and/or normal (Thomas \& Hughes 1982, Thomas et al. 1986, Fievet et al. 1988); this of course is quite the converse of our findings, suggesting that hypoxia per se is not critically involved in the pathogenesis of BGD. Lactate levels are believed to be sensitive indicators of hypoxic stress in trout (Dunn \& Hochachka 1987), when environmental (water) oxygen levels fall below a threshold level of approximately 50 torr (Boutilier et al. 1988) because lactate levels rise as increasing hypoxia boosts the rate of anaerobic metabolism. Wakabayashi \& Iwado (1985) reported reduced levels of muscle lactate from rainbow trout experimentally infected with BGD. They concluded that these low levels provided evidence to support the idea of an hypoxic event associated with BGD. We believe however that decreased lactate levels do not support the concept of hypoxemia as a primary disturbance; indeed quite the converse is true. In our study, lactate levels were no different between normal and diseased fish, supporting the concept that the sick fish were not hypoxic. More support for this argument can be found in the fact that a fish with tachybranchia responding to minor hypoxia would tend to have a respiratory alkalosis (reducing $\mathrm{pCO}_{2}$ and thus increasing $\mathrm{pH}$ ) (Boutilier et al. 1988) while $\mathrm{pO}_{2}$ levels would remain normal, if compensation were successful, or decreased slightly if unsuccessful. These trends were not observed in our findings, although changes in acidbase status may have been missed by our sampling design. Whatever the stimulus for the tachybranchia observed in BGD, the result of increased water flow over an enlarged area (due to lamellar recruitment) of damaged respiratory membrane would probably be to exacerbate the trends seen in electrolyte losses. In summary, we believe that hypoxia may contribute, but only in a secondary way, to the primary cause of BGD associated fatality, that of disrupted electrolyte balance.

Ion losses similar to those seen in the BGD fish are also seen in trout exposed to acid conditions in soft water, resulting in circulatory failure and death brought on by haematological and fluid volume disturbances (Milligan \& Wood 1982, Wood \& McDonald 1982). Dilution of plasma ions also occurs during various life stages of anadromous salmon (Miles 1971, Stuart \& Morris 1985), but the changes are not fatal. In light of this apparent contradiction, it has been proposed recently (Wood 1988) that naturally-occurring seasonal blood electrolyte disturbances of salmonids may take longer to develop, and thus are unlikely to be as traumatic to the fish. Wood suggests that the faster rate of ion loss in trout experiencing acid-stress in soft water is the factor triggering the haematological disturbances that lead to death. The relatively short period of time (ca $24 \mathrm{~h}$ ) in which BGD can overcome a trout population (Ferguson et al. in press) means that rapid reductions in serum ions could have occurred, similar therefore to the severely acid-stressed trout. In addition to the loss of osmotically active electrolytes $\left(\mathrm{Na}^{+}\right.$and $\mathrm{Cl}^{-}$) the BGD-infected fish had increased serum protein and increased pcv, suggesting haemoconcentration. Similar changes were reported in fish from a variety of environmental situations in which waterborne irritants induce impairment of gill function(s) (Albassam et al. 1987, Booth et al. 1988, Wood et al. 1988, Byrne et al. 1989). Wood (1988) believes that changes such as these are in part responsible for death in some situations of acid-stress, when the initial event of ion dilution leads to a fluid shift from extracellular to intracellular compartments which in turn can produce haemoconcentrated, highly viscous blood. We also believe that such a shift was responsible (in part) for the increased pcv and serum proteins in BGD-infected trout. Other factors, not directly related to ion dilution, may also have contributed to the haemoconcentration including, for example, stress- and/or hypoxemicinduced release of catecholamines which cause swelling of erythrocytes, thus increasing the pcv (Nikinmaa 1982, Baroin et al. 1984, Motais et al. 1989). The mechanism(s) for ion dilution in these fish may be quite unlike those of trout with BGD, but the sequelae and eventual outcome may nevertheless be similar.

Associated with BGD are diffuse gill epithelial damage (Speare et al. in press) and excess mucus production (Ferguson 1989). Both cell damage and excess 


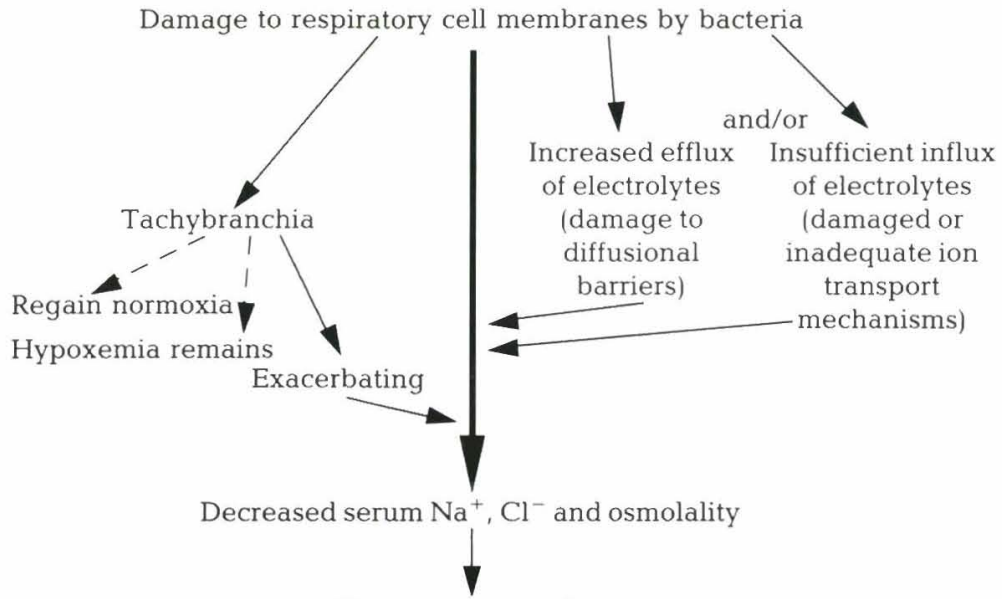

Haemoconcentration (Fluid shift from extracellular to intracellular compartments)

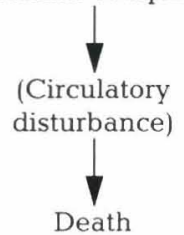

Fig. 2. Proposed model to explain the pathogenesis and pathophysiology of bacterial gill disease in Salvelinus fontinalis

mucus may contribute to increased diffusive distances of $\mathrm{O}_{2}$ and $\mathrm{CO}_{2}$ initiating and/or contributing to hypoxemia (Ultsch \& Gros 1979). As discussed, the relevance of hypoxia to BGD remains unclear. More importantly however, damage to respiratory epithelial cells, including apical membranes and intercellular junctional complexes, and membrane-associated enzymes (i.e. ATPases, cAMP and carbonic anhydrase) involved in ion and gas regulation (McDonald et al. 1988, Laurent \& Hebibi 1989, McDonald \& Prior 1989, Perry \& Wood 1989) could disrupt normal ion fluxes and gas exchange. The damage induced by BGD organisms and the irritation that follows (as suggested by increased mucus production and, in chronic situations, lamellar hyperplasia and fusion) suggest that the decrease in serum $\mathrm{Na}^{+}$and $\mathrm{Cl}^{-}$occurs because of increased efflux (via increased diffusive loss) and possibly, impeded (active) influx. Moreover, as reported with hypoxemic trout, plasma electrolyte shifts can be almost entirely internal with little contribution from changes in branchial flux rates (Thomas et al. 1986). Thus, interpreting disturbances in the branchial flux rates associated with BGD may be complicated by the oxygen status of the fish.

The dramatic shift in blood electrolytes was seen in relatively big fish, and it seems reasonable to suggest that small fish would be much more vulnerable to such a shift, owing to a smaller ionic reserve. Thus the changes reported here may be more dramatic and occur more slowly over a longer period of time than those encountered in fry or fingerlings. Regardless of the rate of ionic fluxes, the speed with which therapy must be instituted is well known from practical experience particularly in small fish which die very quickly. The results presented here support the concept of chemical treatment to kill the bacteria, combined with other supportive measures, in particular with an attempt to help redress the ion balance, possibly by adding salt to the water. Of course, any possibility of increasing the oxygen levels may also help, by reducing the tachybranchia, and possibly thereby the ion loss. Alternative explanations for why small fish are more susceptible to BGD infection could include a relatively poorly developed immune system, in particular the non-specific mechanisms at the gill surface, or possibly inefficient clearance mechanisms.

Alterations in branchial flux rates, acid-base status and gaseous exchange need to be verified using improved sampling and analytical procedures. In light of the fact that BGD can now be experimentally reproduced in our laboratory (Ferguson et al. in press) it will be possible to provide a more controlled environment to accurately evaluate blood chemistry changes associated with this disease. Using an indwelling arterial catheter and keeping the fish in a light-reduced container should enable blood sampling from unanaesthetized, relatively undisturbed fish.

Acknowledgements. Diane Morrison and Chris Lewis provided excellent technical assistance. The Fish Pathology Laboratory is partially funded by the Ontario Ministry of Agriculture and Food. 


\section{LITERATURE CITED}

Albassam, M., Moore, J., Sharma, A. (1987). Ultrastructural and clinicopathological studies on the toxicity of cationic acrylamide-based flocculant to rainbow trout. Vet. Pathol. 24: $34-43$

Baroin, A., Garcia-Romeu, F., Lamarre, T., Motais, R. (1984). Hormone induced cotransport with specific pharmacological properties in erythrocytes of rainbow trout, Salmo gairdneri. J. Physiol. 350: 137-157

Booth, C. E., McDonald, D. G., Simons, B. P., Wood, C. M. (1988). Effects of aluminum and low $\mathrm{pH}$ on net ion fluxes and ion balance in the brook trout (Salvelinus fontinalis). Can. J. Fish. Aquat. Sci. 45: 1563-1574

Boutilier, R. G., Dobson, G., Hoeger, U., Randall, D. J. (1988). Acute exposure to graded levels of hypoxia in rainbow trout (Salmo gairdneri): metabolic and respiratory adaptations. Respir. Phys. 71: 69-82

Bullock, G. L. Herman, R. L. (1988). Control of bacterial gill disease with Chloramine-T. Res. Inform. Bull., U.S. Dept Interior, Fish and Wildlife Serv. No. 88-18

Byrne, P., Speare, D., Ferguson, H. W. (1989). Effects of a cationic detergent on the gills and blood chemistry of rainbow trout Salmo gairdneri. Dis. aquat. Org. 6: 185-196

Daoust, P. Y., Ferguson, H. W. (1983). Gill diseases of cultured salmonids in Ontario. Can. J. Comp. Med. 47: 358-362

Dunn, J. F., Hochachka, P. W. (1987). Turnover rates of glucose and lactate in rainbow trout during acute hypoxia. Can. J. Zool. 65: 1144-1148

Ferguson, H. W. (1989). Systemic pathology of fish. Iowa State University Press, Ames

Ferguson, H. W., Ostland, V. E., Byrne, P., Lumsden, J. S. Experimental production of bacterial gill disease in trout by horizontal transmission and by bath challenge. J. aquat. Anim. Health (in press)

Fievet, B., Claireaux, G., Thomas, S., Motais, R. (1988). Adaptive respiratory responses of trout to acute hypoxia. III. Ion movements and $\mathrm{pH}$ changes in the red blood cell. Respir. Phys. 74: 99-114

Heming, T. A. (1989). Clinical studies of fish blood: importance of sample collection and measurement techniques. Am. J. Vet. Res. 50: 93-97

Hollander, M., Wolfe, D. A. (1973). Nonparametric statistical methods. John Wiley and Sons, Inc.. New York

Kudo, S., Kimura, N. (1983). Transmission electron microscopic studies on bacterial gill disease in rainbow trout fingerlings. Jap. J. Ichthyol. 30: 247-260

Kudo, S., Kimura, N. (1984). Scanning electron microscopic studies on bacterial gill disease in rainbow trout fingerlings. Jap. J. Ichthyol. 30: 393-403

Laurent, P., Hebibi, N. (1989). Gill morphometry and fish osmoregulation. Can. J. Zool. 67: 3055-3063

McDonald, D. G., Tang, Y., Boutilier, R. G. (1988). Acid and ion transfer across the gills of fish: mechanisms and regulation. Can. J. Zool. 67: 3046-3054

McDonald, D. G., Prior, E. T. (1989). Branchial mechanisms of ion and acid-base regulation in the freshwater rainbow trout, Salmo gairdneri. Can. J. Zool. 66: 2699-2708

Miles, H. M. (1971). Renal function in migrating adult coho salmon. Comp. Biochem. Physiol. 38A: 787-826

Milligan, C. L., Wood, C. M. (1982). Disturbances in haematology, fluid volume distribution, and circulatory function

Responsible Subject Editor: Professor O. Kinne, Oldendorf/ Luhe, Germany associated with low environmental $\mathrm{pH}$ in the rainbow trout, Salmo gairdneri. J. exp. Biol. 99: 397-415

Motais, R., Fievet, B., Garcia-Romeu, F., Thomas, S. (1989). $\mathrm{Na}^{+}-\mathrm{H}^{+}$exchange and $\mathrm{pH}$ regulation in red blood cells: role of uncatalyzed $\mathrm{H}_{2} \mathrm{CO}_{3}$ dehydration. Am. J. Physiol. 256: C728-C735

Nikinmaa, M. (1982) Effects of adrenalin on red cell volume and concentration gradient of protons across the red cell membrane in the rainbow trout Salmo gairdneri. Mol. Physiol. 2: 287-297

Ostland, V. E., Ferguson, H. W., Prescott, J. F., Stevenson, R. M. W., Barker, I. K. (1990). Bacterial gill disease of salmonids; relationship between the severity of gill lesions and bacterial recovery. Dis. aquat. Org. 9: 5-14

Perry, S. F., Wood, C. M. (1989). Control and coordination of gas transfer in fishes. Can. J. Zool. 67: 2961-2970

Rucker, R. R., Johnson, H. E., Kaydas, G. M. (1952). An interim report on gill disease. Progve. Fish Cult. 14: 10-14

Satterthwaite, F. W. (1946). An approximate distribution of estimates of variance components. Biometrics Bull. 2: 110-114

Speare, D. J., Ferguson, H. W. (1989). Clinical features of bacterial gill disease of salmonids in Ontario. Can. Vet. J. 30: 882-887

Speare, D. J., Ferguson, H. W. Beamish, F. W. M., Yager, J. A., Yamashiro, S. (1991a). Pathology of bacterial gill disease: sequential development of lesions during natural outbreaks of disease. J. Fish Dis. (in press)

Speare, D. J., Ferguson, H. W., Beamish, F. W. M., Yager, J. A., Yamashiro, S. (1991b). Pathology of bacterial gill disease: ultrastructure of branchial lesions. J. Fish Dis. (in press)

Stuart, S., Morris, R. (1985). The effects of seasons and exposure to reduced $\mathrm{pH}$ (abrupt and gradual) on some physiological parameters in brown trout (Salmo gairdneri). Can. J. Zool. 63: 1078-1083

Thomas, S., Hughes, G. M. (1982). A study of the effects of hypoxia on acid-base status of rainbow trout blood using anextracorporeal blood circulation. Respir. Phys. 49: 371-382

Thomas, S., Fievet, B., Motais, R. (1986). Effects of deep hypoxia on acid-base balance in trout: role of ion transfer processes. Am. J. Physiol. 250: R319-R327

Ultsch, G. R., Gros, G. (1979). Mucus as a diffusion barrier to oxygen: possible role in $\mathrm{O}_{2}$ uptake at low $\mathrm{pH}$ in carp (Cyprinus carpio) gills. Comp. Biochem. Physiol. 62A: 685-689

Wakabayashi, H., Iwado, T. (1985). Changes in glycogen, pyruvate and lactate in rainbow trout with bacterial gill disease. Fish Path. 20: 161-165

Wood, C. M. (1988). The physiological problems of fish in acid waters. In: Morris, R., Taylor, E. W., Brown, D. J. A., Brown, J. A. (eds.) Acid toxicity and aquatic animals. Society for experimental biology Ser. 34. Cambridge University Press, Cambridge, p. 125-152

Wood, C. M., McDonald, D. G. (1982). Physiological mechanisms of acid toxicity to fish. In: Johnson, R. E. (ed.) Acid rain/fisheries. American Fisheries Society, Bethesda, p. 197-226

Wood, C. M., Playle, R. C., Simons, B. P., Goss, G. G., McDonald, D. G. (1988). Blood gases, acid-base status, ions, and hematology in adult brook trout (Salvelinus fontinalis) under acid/aluminum exposure. Can. J. Fish. Aquat. Sci. 45: 1575-1586

Manuscript first received: August 2, 1990

Revised version accepted: November 12, 1990 